\title{
東京タワーの塗装による維持保 MAINTENANCE OF TOKYO TOWER 全 BY COATING SYSTEMS
}

\section{大澤 悟— $* 1$ 本橋健司— $* 2$}

キーワード :

鋼構造物，東京タワー，塗装，維持保全

Keywords:

Steel construction, Tokyo tower, Coating systems, Maintenance

\section{Satoru OHSAWA —— $* 1 \quad$ Kenji MOTOHASHI- $* 2$}

Tokyo Tower has passed for 55 years till today at the end of 1958 since completion. In the meantime, though it is a large-sized steel construction which is easy to corrode, by suitable maintenance preservation by coatings, without spoiling a fine sight function, a ground protection feature, etc., the function it is supposed that it is as a communications tower and a sightseeing spot is held, and nine renewal coating work is carried out till the present.

This paper reports the maintenance preservation by the application coating systems at the time of this construction, and subsequent whole surface renewal coatings.

\section{1.はじめに}

東京タワーは、1958 年 12 月末に竣工以来、今日まで 55 年経過 し ている。この間、腐食しやすい大型鋼構造物でありながら、塗装に よる適切な維持保全により、美観機能や下地保護機能等を損なうこ となく、電波塔や観光スポットとしての機能を保持してきており、

現在まで 9 回の全面塗替塗装工事を実施してきている。

本報では、この東京タワー建設時における適用塗装システム ${ }^{1)}$ 及 びその後の全面塗替塗装による維持保全 ${ }^{2)}$ ～5) について報告する。

\section{2. 東京タワーの建築概要}

東京タワーは、鉄塔本体と近代科学を紹介寸るための科学館とで 構成されている。その建築概要を、以下に示す。

鉄塔本体の高さは、 $110 \mathrm{~km}$ 以内の関東一円をサービスエリアとす る必要から、エッフェル塔よりも $18 \mathrm{~m}$ 高い $333 \mathrm{~m}$ で設計された。

施主：日本電波塔㑣

設計指導 : 工学博士 内藤多仲

設計監理：日建設計工務㑣)

施工：(株竹中工務店

所 在 地: 東京都港区芝公園 20 号地 1 番

敷地面積: $21,002.8 \mathrm{~m}^{2}$

$$
\begin{array}{ll}
\text { 工 } & \text { 期 : } 1957 \text { 年 } 6 \text { 月 } 29 \text { 日〜 1958 年 } 12 \text { 月 } 23 \text { 日 } \\
\text { 構 } & \text { 造 : 基礎（R C 深礎工法), 塔体 }(\mathrm{S} \text { 造 }) \\
\text { 高 } & \text { さ: } 333 \mathrm{~m} \text { （標準 G. L 避雷針頂部） }
\end{array}
$$

使用鋼材 : 4, 000t（塔本体：SS41 規格品, アンテナ支持台 : SHT52 相当品)

部材接合：リベット 168,000 本（鋼材）, 本締ボルト 45,000 本（亜鉛めっき鋼材）

\section{3. 建設時の塗装システム}

鉄塔本体に採用された塗装システム を表 1 に、その塗装区分である鋼材へ の適用部位（梁 No.）を図 1 に示す。

地上から塔頂 $(\mathrm{H} 27)$ までの鉄塔本体 の部材は、地上から H14 までは鉄鋼、 高さ $150 \mathrm{~m}$ 以上の H14 から H27 までの部 材は、高所での防錆性を考慮して溶融 亜鉛めっき鋼（以下、亜鉛めっき鋼と 称す）で構成された。

適用塗装システムは、今日のような ふっ素樹脂系やアクリルシリコン樹脂 系等の高耐候性塗装系が存在しなかっ た時代であり、当時における船舶・橋 梁等大型鋼構造物での施工実績等を踏 まえて、橋梁用のマリンペイントである

\begin{tabular}{|c|c|c|c|c|c|c|c|c|}
\hline 部位 & 素地 & 区分 & & 工程 & 塗料その他 & $\begin{array}{l}\text { 塗布量 } \\
\left(\mathrm{kg} / \mathrm{m}^{2}\right)\end{array}$ & $\begin{array}{c}\text { 乾燥膜厚 } \\
(\mu \mathrm{m})\end{array}$ & $\begin{array}{c}\text { 放置時間 } \\
\text { (h) }\end{array}$ \\
\hline \multirow{4}{*}{$\begin{array}{c}\mathrm{H} 27 \\
\mathrm{~S} \\
\mathrm{H} 14\end{array}$} & \multirow{4}{*}{$\begin{array}{c}\text { 亜 } \\
\text { 鉛 } \\
\text { め } \\
\text { } \\
\text { き } \\
\text { 鋼 }\end{array}$} & \multirow{4}{*}{$\begin{array}{l} \\
\text { 現 } \\
\text { 場 } \\
\text { 塗 } \\
\text { 装 }\end{array}$} & \multicolumn{2}{|r|}{ 素地調整 } & \multicolumn{4}{|c|}{$\begin{array}{l}\text { 污れ·付着物の除去 } \\
\text { 発錆部は下塗り塗料で補修塗り }\end{array}$} \\
\hline & & & 2 & 下 塗 り & $\begin{array}{l}\text { ジンククロメート系 } \\
\text { さび止めペイント }\end{array}$ & 0.16 & 25 & 10 \\
\hline & & & 3 & 中 塗 り & フタル酸樹脂系塗料 & 0.14 & 20 & 16 \\
\hline & & & 4 & 上塗り & フタル酸樹脂系塗料 & 0.13 & 20 & 16 \\
\hline \multirow{6}{*}{$\begin{array}{c}\mathrm{H} 14 \\
\mathrm{~S} \\
\text { 地上 }\end{array}$} & \multirow{6}{*}{$\begin{array}{l}\text { 鉄 } \\
\text { 鋼 }\end{array}$} & 工場 & 1 & 素地調整 & サンドブラストで除錆後、 & ヨッププラ & マ一塗り & \\
\hline & & 塗装 & 2 & 下塗り1回目 & 鉛丹系さび止めペイント & 0.20 & 25 & 12 \\
\hline & & \multirow{4}{*}{$\begin{array}{l}\text { 現 } \\
\text { 場 } \\
\text { 塗 } \\
\text { 装 }\end{array}$} & 3 & 下地調 整 & \multicolumn{4}{|c|}{$\begin{array}{l}\text { 污れ·付着物の除去 } \\
\text { 発錆部は下塗り塗料で補修塗り }\end{array}$} \\
\hline & & & 4 & 下塗り2回目 & 鉛丹系さび止めペイント & 0.20 & 25 & 12 \\
\hline & & & 5 & 中 塗り & フタル酸樹脂系塗料 & 0.14 & 20 & 16 \\
\hline & & & 6 & 上塗り & フタル酸樹脂系塗料 & 0.13 & 20 & 16 \\
\hline
\end{tabular}

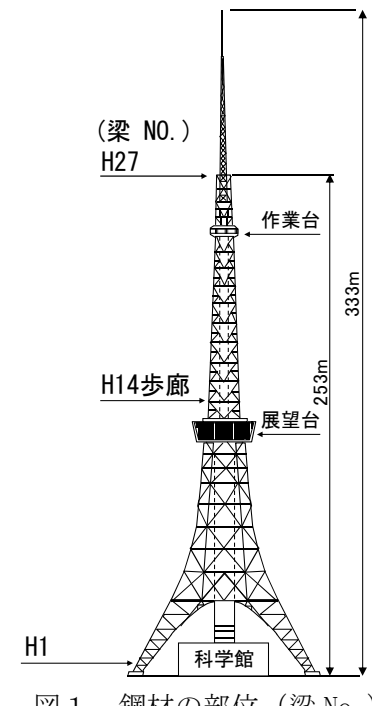

表 1 建設時の塗装システム

*2 Prof., Dept. of Architecture and Building Engineering, Shibaura Institute of Technology, Dr. Eng. 
フタル酸樹脂系塗装システムが採用された。すなわち、地上から H14 までの鉄鋼面は、工場でサンドブラスト処理後、ショッププライマ 一塗り及び鉛丹系さび止めペイント 1 回塗りまでを行い、現地搬 入・建方後、下地調整を施してから 2 回目の下塗り（下塗り 1 回目 と同じ鉛丹系）を全面に塗装後、フタル酸樹脂系塗料の中塗り及び 上塗りが塗装された。また、H14から塔頂までの亜鉛めっき鋼面は、 工場で酸洗い及び溶融亜鉛めっき処理を施し、現地搬入・建方後、 污れ・付着物等を除去し、下塗りとしてジンククロメート系さび止 めペイントを 1 回塗装し、鉄鋼面と同じフタル酸樹脂系塗料の中塗 り及び上塗りが塗装された。なお、リベットやボルト頭、エッジ部 等他の部材に比べて発錆し易い箇所は、下塗りによる増し塗りが行 われた。この鉄塔本体の全塗装面積は、約 $78,000 \mathrm{~m}^{2}$ (塗料使用量 : 約 28,000り）であり、現地での塗装作業は、1958 年 11 月から 12 月 までの約 1.5 ケ月間で実施された。また、塔体の彩色は、当時の航 空法に従って白とインターナショナルオレンジ(以下、黄赤と称す) を塗り分けたしま模様となった。但し、この彩色区分は、その後の 航空法の改正に伴って何度か変更になっている。

\section{4．塗装による維持保全}

\section{1 維持保全の基本的な考え方}

塗料は、合成樹脂を主とする有機材料で構成されており、紫外線・ 降雨水等大気中の外力により経年に伴って、表面から損耗・劣化し ていく。従って、適切な塗替塗装を行うことによって、美観や下地 保護等所定の性能を維持する必要がある。

大型鋼構造物である東京タワーの塗装による維持保全の基本フロ 一を、図 2 に示す。

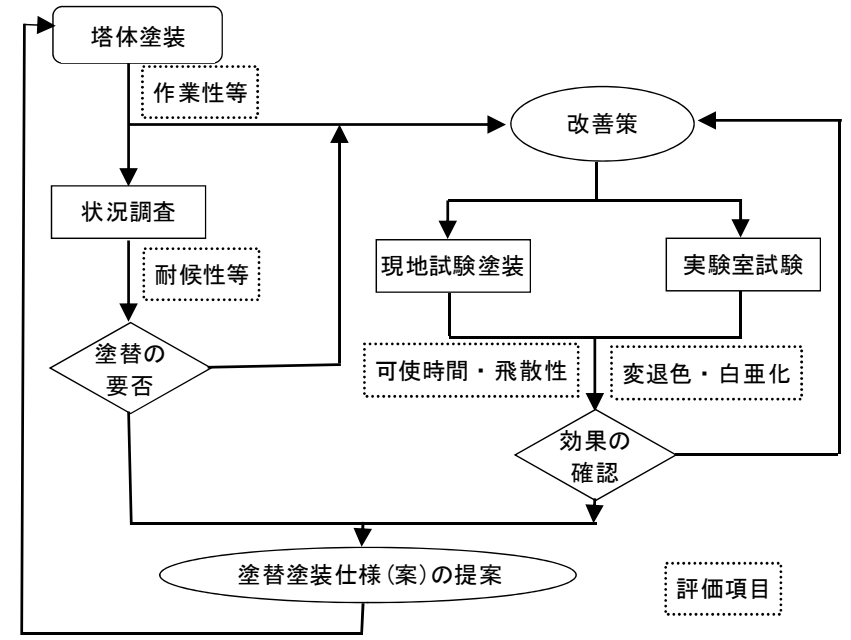

図 2 東京タワーの塗装による維持保全（基本フロー）
なお、この東京タワーの塗装による維持保全では、電波塔や観光 スポットとしての機能保持が最優先である。従って、塗装の全面塗 替時期の判定は、既存塗膜の劣化状況の影響が素地金属（鉄鋼・亜 鉛めっき鋼）にまで及ばないようにする観点から、污れ・変退色等 により塔体全体の美観機能が損なわれ始めた時点を目安としている。

\section{2 塗替塗装システム}

東京タワーの塗装による維持保全として実施してきた全面塗替塗 装システム（以下、塗替塗装と称す）を、表 2 に示す。

素地である鉄鋼や亜鉛めっき鋼は、大気中の水分や酸素との接触 により腐食が進行し、海塩粒子や亜硫酸ガス等により腐食が促進さ れる。従って、塗装による維持保全で鉄塔本体の防錆性を確保・維 持するには, 既存塗膜に塗替塗膜を出来るだけ塗り重祙ることによ り、腐食因子や腐食促進因子と素地金属との接触を遮断するのが最 も効果的であるとの判断に基づき、塗り重㸚による塗替塗装を採用 してきている。

よって、東京タワーにおける塗替塗装の作業は、既存塗膜の健全 部はできるだけ塗替塗装の下地として生かし, 既存塗膜の劣化部分 のみ [下地調整 $]$ であるケレン・清掃作業を実施し、その部分及び 周辺にのみ［補修塗り］である下叙り（さび止めペイント）を行い、 既存塗膜の健全部及び [補修塗り]部を塗装下地として、全面に [中 塗り］及び［上塗り］を塗装する工程を採用してきている。以上の 各塗替塗装工程における作業内容や使用塗料等を、次に示す。

\section{（1）下地調整}

[下地調整］は、既存塗膜の劣化部分である浮き・はが部や、 露出した素地金属の発錆部を、ケレン・清掃する工程である。また、 既存塗膜の健全部は、そのまま塗替塗装工程の [中塗り］下地とし て活用出来るように、塗膜表面の清掃を実施している。

\section{（2）補修塗り}

［補修塗り］は、[下地調整］を行った既存塗膜の劣化部分及びそ の周辺部を、下塗り（さび止め）にて拾い塗りする工程である。こ の工程で使用してきた塗料は、亜鉛めっき鋼面及び鉄鋼面とも以下 に示寸既存塗膜の状況が見られ、建設時から変更してきている。

(1)亜鉛めっき鋼の場合

建設後の比較的早い時期から、部分的に塗膜のわれやはがれの発 生が幾つか認められた。但し、塗膜がはがれて露出した亜鉛めっき 鋼の表面は、部分的な白さび発生程度であり、赤さびの流出にまで 至っている箇所は認められなかった (写真 1 参照)。また、はがれの 発生は、いずれも亜鉛めっき鋼面と建設時の下塗り（ジンククロメ 一ト系）との界面で生じていた。

\section{表 2 全面塗替時の塗装システム}

東京タワーでは、既存塗膜の状沉調査を適 宜行いながら現状を把握して塗替塗装の要否 を判断している。また、採用した塗替塗装シ ステムの作業性・耐候性等を実施工により評 価しながら、問題点の改善策を立案し、その 効果を現地試験施工や実験室試験等により確 認している。以上のフローに従って、東京タ ワーにより適した塗替塗装システムの選定を 行っている。

\begin{tabular}{|c|c|c|c|c|c|c|c|c|c|c|c|}
\hline 部位 & $\begin{array}{l}\text { 素 } \\
\text { 地 }\end{array}$ & 工程 & $\begin{array}{l}\text { 第1回 } \\
(1965) \\
\end{array}$ & $\begin{array}{l}\text { 第2回 } \\
(1970) \\
\end{array}$ & $\begin{array}{l}\text { 第3回 } \\
(1976) \\
\end{array}$ & $\begin{array}{l}\text { 第4回 } \\
(1980) \\
\end{array}$ & $\begin{array}{l}\text { 第5回 } \\
(1986) \\
\end{array}$ & $\begin{array}{l}\text { 第6回 } \\
(1991) \\
\end{array}$ & $\begin{array}{l}\text { 第7回 } \\
(1996) \\
\end{array}$ & $\begin{array}{l}\text { 第8回 } \\
(2002) \\
\end{array}$ & $\begin{array}{l}\text { 第9回 } \\
(2007) \\
\end{array}$ \\
\hline \multirow{4}{*}{$\begin{array}{c}\mathrm{H} 27 \\
\mathrm{~S} \\
\mathrm{H} 14\end{array}$} & \multirow{4}{*}{$\begin{array}{c}\text { 亜 } \\
\text { 鉛 } \\
\text { め } \\
\text { ? } \\
\text { き } \\
\text { 鋼 }\end{array}$} & 下地調整 & \multicolumn{9}{|c|}{ 劣化塗膜の除去·発錆部の4種 (ケレン)·清掃 } \\
\hline & & 補修塗り & \begin{tabular}{|l|} 
鉛酸カルジウム \\
さび止めペイント
\end{tabular} & 同左 & 同左 & 同左 & 同左 & 同左 & 同左 & \multicolumn{2}{|c|}{$\begin{array}{c}\text { 1液型弱溶剤系 } \\
\text { 変性エポキシ樹脂 } \\
\text { さび止めペイント }\end{array}$} \\
\hline & & 中塗り & フタル酸樹脂系塗料 & 同左 & 同左 & 同左 & 同左 & 同左 & 同左 & 同左 & 同左 \\
\hline & & 上塗り & フタル酸樹脂系塗料 & 同左 & 同左 & 同左 & 同左 & 同左 & 同左 & 同左 & 同左 \\
\hline \multirow{4}{*}{$\begin{array}{c}\mathrm{H} 14 \\
\mathrm{~S} \\
\text { 地上 }\end{array}$} & \multirow{4}{*}{$\begin{array}{l}\text { 鉄 } \\
\text { 鋼 }\end{array}$} & 下地調整 & \multicolumn{9}{|c|}{ 劣化塗膜の除去·発錆部の4種(ケレン)·清掃 } \\
\hline & & 補修塗り & $\begin{array}{l}\text { 鉛丹系 } \\
\text { さび止めペイント }\end{array}$ & $\begin{array}{l}\text { ※特殊さ } \\
\text { び止めペ } \\
\text { イント }\end{array}$ & 同左 & 同左 & 同左 & 同左 & 同左 & \multicolumn{2}{|c|}{$\begin{array}{c}\text { 1液型弱溶剤系 } \\
\text { 変性エポキシ樹脂 } \\
\text { さび止めペイント }\end{array}$} \\
\hline & & 中塗り & フタル酸樹脂系塗料 & 同左 & 同左 & 同左 & 同左 & 同左 & 同左 & 同左 & 同左 \\
\hline & & 上塗り & フタル酸樹脂系塗料 & 同左 & 同左 & 同左 & 同左 & 同左 & 同左 & 同左 & 同左 \\
\hline
\end{tabular}




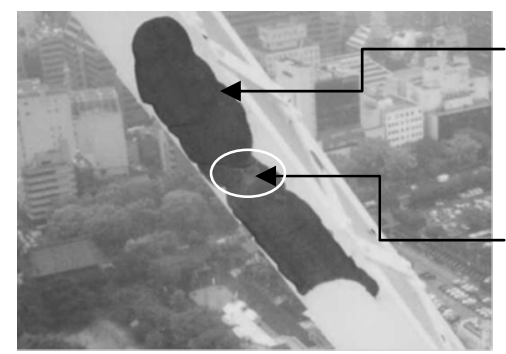

建設時の下塗り（ジン ククロメート系）塗膜 からのわれ・はがれ

露出した亜鉛めっき鋼 表面の白さび

写真 1 亜鉛めっき鋼面の塗膜状況（2001 年度調査）

この塗膜のはがれの原因は、その状況から下塗りに使用したジン ククロメート系の脆化に伴う亜鉛めっき鋼への付着性低下に起因す ると推定された。従って、第 1 回目（1965 年）の塗替塗装から、よ り付着信頼性の高い「鉛酸カルシウムさび止めペイント」を[補修 塗り］に採用し、第 7 回目（1996 年）の塗替塗装まで使用した。こ の [補修塗り]部の亜鉛めっき鋼面と鉛酸カルシウム系との付着性 は、その後の 30 年間の状況調査でも良好であり、ジンククロメー 卜系の場合のような塗膜のはがれは認められない状況であった。

本来であれば、比較的初期から発生した亜鉛めっき鋼界面で塗膜 のはがれの原因となった建設時のジンククロメート系を全面除去し て、鉛酸カルシウム系に置き換えるのが最善の策であるが、このジ ンククロメート系に起因した塗膜のはがれは、経年に伴って徐々に 進行しており、塗替塗装毎にジンククロメート系に起因して発生し たはがれ部分を、鉛酸カルシウム系にて [補修塗り]することによ り、残存するジンククロメート系を鉛酸カルシウム系に置き換える 手法を採用した。しかし、この手法による [補修塗り］作業だけで は全面的に代替することが困難であり、ジンククロメート系が想定 以上に残っていた。特に、 40 年以上経過した第 8 回塗替 (2002 年) 前の調查では、第 7 回目までの中塗り及び上塗りの塗り重ねにより $700 \mu \mathrm{m}$ を超える膜厚となり、ジンククロメート系と亜鉛めっき鋼面 との付着性がより低下したと推定される界面からの塗膜はがれが、 今まで以上に散見されるようになり、塗替塗膜の経年に伴う付着性 の低下が、より懸念される状況であった（写真 2 参照)。
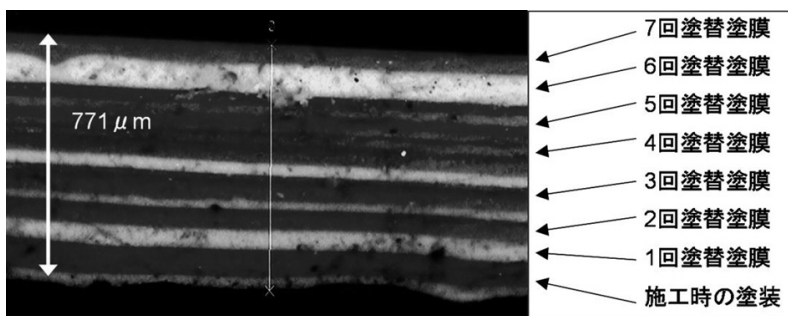

写真 2 亜鉛めっき鋼面から自然にはがれた塗膜の 断面状況（2002 年採取）

そのため、過去の実績等も踏まえて、既存塗膜への浸透性が良好 で、鉛酸カルシウム系よりも亜鉛めっき鋼面との付着性が期待でき る「 1 液形弱溶剂系変性エポキシ樹脂さび止めペイント」を[補修 塗り）として、第 8 回（2002 年）の塗替塗装から採用しており、こ の [補修塗り]部の付着性は、現在まで特に問題のない状況である。 (2)鉄鋼の場合

亜鉛めっき鋼のような塗膜のわれやはがれの発生は認められなか った。また、一部のリベット頭や部材エッジで、打ち傷等に伴う塗 膜の損傷による点さび程度の表面さびの発生は認められたものの、 全体的には良好な塗膜状態であった（写真 3 参照）。

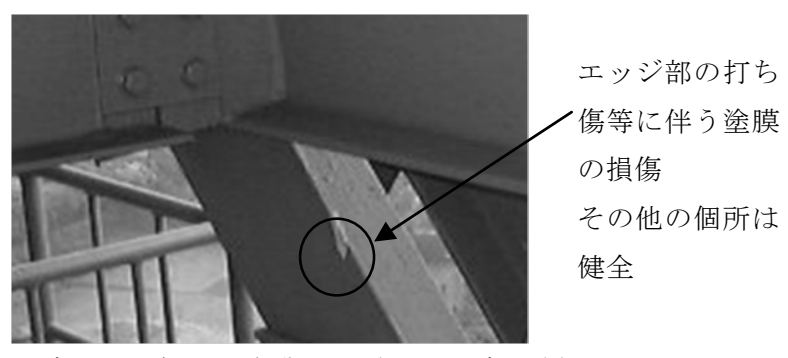

写真 3 鉄鋼面の塗膜状況（2001 年度調查）

鉄鋼面の場合、建設時の下塗り及び第 1 回（1965 年）の塗替塗装

の[補修塗り]に鉛丹系さび止めを用いていたが、その後の健全な 塗膜状況を踏まえて、第 2 回目（1970 年）の塗替塗装から、防錆性 が鉛丹系と同等でより乾燥性や作業性の良い「特殊さび止めペイン 卜 (防錆ビヒクルタイプ)」を[補修塗り]に採用し、第 7 回目 $(1996$ 年）の塗替塗装まで使用した。この[補修塗り]部は、2 5 年以上 経過後でも、塗膜のわれ・はがれ等の不具合の発生は、全く認めら れない状況であった。

なお、亜鉛めっき鋼面の [補修塗り］で第８回目（2002 年）の塗 替塗装から採用した「1 液形弱溶剂系変性エポキシ樹脂さび止めぺ イント」が、鉄鋼面でも適用できることを実績等から確認し、塔体 全体の塗装作業で同じ塗料を使用する観点から、鉄鋼面でも【補修 塗りとして同じ第 8 回（2002 年）の塗替塗装から採用しており、 この変性エポキシ樹脂系を使用した［補修塗り］部の付着性は、亜 鉛めっき鋼面と同様、現在まで特に問題のない状況である。

また、鉄鋼面の塗膜状沉として、建設後 55 年経過した鉄鋼面か ら採取した塗膜の断面状況を、写真 4 に示寸。

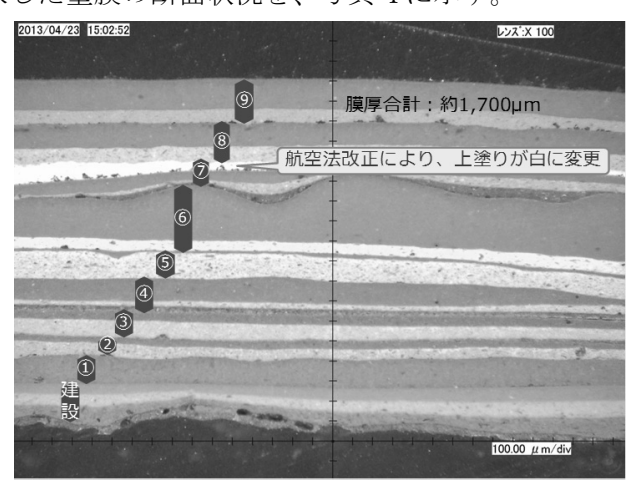

写真 4 鉄鋼面の建設時からの塗膜断面状況（2013 年採取）

これは、2013 年の鉄塔脚部補強工事において、リベットをボルト に交換する際に、リベット近傍から機械的にはがして採取した塗膜 であり、建設時の「鉛丹系さび止めペイント」と「フタル酸樹脂系 塗料」に、第 9 回目までの［中塗り］［上塗り］塗膜が積層されて、 合計約 $1,700 \mu \mathrm{m}$ の膜厚で構成されている状況が確認された。これよ り、建設時に設計仕様に従って適切に素地調整が行われて下塗りと の付着性が確保されていれば、その後の塗替塗装の適用における[中 塗り［上塗り]の塗り重㸚によるふく方・われ・はがれ等の不具合 の発生もなく、今日に至っているものと推定される。

( 3 ) 中塗り・上塗り

[中塗り］及び［上塗り］は、既存塗膜健全部及び補修部の全面 に塗装しており、使用塗料はいずれも建設時と同じフタル酸樹脂系 塗料を採用している。但し、その後に上市された他の塗装システム （シリコーンアルキド樹脂系・塩化ゴム系・ポリウレタン系・アクリ 
ルシリコン樹脂系・ふっ素樹脂系等) は、より耐候性や防錆性等の向 上を目的としており、これらの新しい塗装システムの東京タワーへ の適性を、現地試験塗装（H25 梁、H23〜24 柱、H13 架台等）や実験 室試験等によって検計してきた。これらの内、H $23 \sim 24$ 柱での試験塗 装板による暴露試験状況を写真 5 に、試験結果を図 3 に示す。また これらの試験結果を踏まえた各種塗装システムの東京タワーへの適 合性比較を、表 3 に示す。

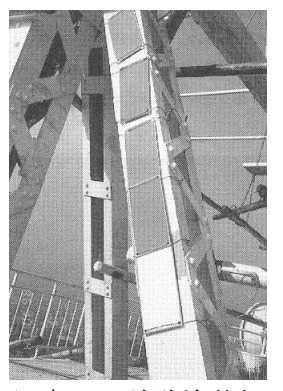

写真 5 試験塗装板の 暴露試験状況

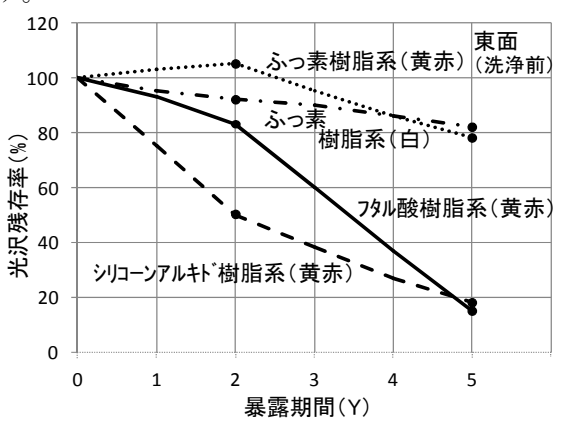

図 3 試験塗装板の光沢変化
表 3 各種塗装システムの適合性比較

\begin{tabular}{|c|c|c|c|c|c|c|c|}
\hline \multicolumn{2}{|l|}{ 評価項目 } & $\begin{array}{l}\text { フ } \\
\text { タ } \\
\text { ル } \\
\text { 酸現 } \\
\text { 樹 } \\
\text { 脂 } \\
\text { 系 }\end{array}$ & $\begin{array}{r}\text { ア } \\
\text { シル } \\
\text { リキ } \\
コ ト ゙ \\
\text { I樹 } \\
\text { ン脂 } \\
\text { 系 }\end{array}$ & $\begin{array}{l}\text { 塩 } \\
\text { 化 } \\
\text { ゴ } \\
\text { 台 } \\
\text { 系 }\end{array}$ & $\begin{array}{l}\text { ポ } \\
\text { リ } \\
\text { ウ } \\
\text { L } \\
\text { タ } \\
\text { 系 }\end{array}$ & $\begin{array}{c}\text { シ } \\
\text { アリ } \\
\text { クコ } \\
\text { リン } \\
\text { ル樹 } \\
\text { 脂 } \\
\text { 系 }\end{array}$ & $\begin{array}{c}\text { 小 } \\
\text { 素 } \\
\text { 樹 } \\
\text { 脂 } \\
\text { 系 }\end{array}$ \\
\hline \multirow{2}{*}{$\begin{array}{c}\text { 既存塗膜 (フタル } \\
\text { 酸樹脂系) との } \\
\text { 適合性 }\end{array}$} & 活 膜 部 & (○) & () & $\mathrm{O}$ & $\triangle$ & $\Delta$ & $\triangle$ \\
\hline & 付着性低下部 & 0 & 0 & $O \sim \triangle$ & $x$ & $x$ & $x$ \\
\hline \multirow{2}{*}{$\begin{array}{c}\text { 素地との } \\
\text { 付着性 }\end{array}$} & 亜鉛めっき鋼 & $\triangle$ & $\triangle$ & $\mathrm{O}$ & (2) & (2) & ()) \\
\hline & 鉄鋼 & $\triangle$ & $\triangle$ & 0 & (2) & (2) & () \\
\hline \multirow{2}{*}{ 施工性 } & 高 & () & () & $O \sim \triangle$ & $\triangle$ & $\triangle$ & $\triangle$ \\
\hline & - & () & () & 0 & $O \sim \triangle$ & $O \sim \triangle$ & $O \sim \triangle$ \\
\hline \multicolumn{2}{|c|}{ 耐 候 性 } & $\Delta$ & $\Delta$ & $O \sim \triangle$ & 0 & () $\sim 0$ & () \\
\hline \multicolumn{2}{|c|}{ 耐 水 性 } & $\Delta$ & $O \sim \triangle$ & 0 & (2) & () & (2) \\
\hline \multicolumn{2}{|c|}{ 周辺への飛散 } & $\triangle$ & $O \sim \triangle$ & 0 & 0 & 0 & 0 \\
\hline \multicolumn{2}{|c|}{ 実績（鋼構造物） } & () & $\Delta \sim \times$ & $\mathrm{O}$ & 0 & $\Delta \sim x$ & $\triangle$ \\
\hline \multicolumn{2}{|l|}{ コ } & (2) & 0 & $O \sim \triangle$ & $\triangle$ & $\Delta \sim x$ & $x$ \\
\hline
\end{tabular}

シリコーンアルキド樹脂系や塩化ゴム系の耐候性は、現行のフタ ル酸樹脂系と大差ない結果であり、またポリウレタン系やふっ素樹 脂系等は、耐候性や素地との付着性に優れるものの、既存塗膜との 適合性、2 液形であることによる施工性等が劣る結果であった。

従って、既存塗膜との適合性、施工性、過去の実績等を考慮して、 現行のフタル酸樹脂系塗料が良いと判断して今日まで採用してきた。 但し、適用するフタル酸樹脂系塗料は、既存塗膜の上に直接塗り重 ねる面積が多いため、下地となる既存塗膜の劣化状況に応じた付着 性、施工性、飛散性等に配慮した塗装設計となっている。

(4) 塗替塗装作業

実際の塗替塗装作業の内、[下地調整］及び［補修塗り］の状況を 写真 6 に示す。

塗替塗装作業は、まず丸太足場や部材の上で [下地調整 $]$ を行い、 次いで地上で希釈した塗料を必要量だけ持って[補修塗り]を行い、 追っかけて全面に［中塗り］と［上塗り］を刷毛で塗り重初ている。 また工事は、塔頂から大展望台までの塗装作業を先行し、次いで大 展望台から地上までの塗装を実施している。なお、作業時間は、夜 間から東京タワーの営業開始時間前までに制限されている。

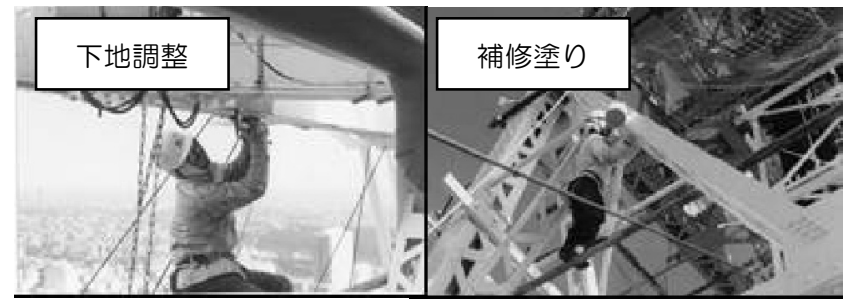

写真 6 塗替塗装作業の状況

5.まとめ

東京タワー建設時における適用塗装システム及びその後の全面塗 替塗装による維持保全状況を、まとめて以下に示す。

(1)1958 年に竣工した東京タワーの部材は、鉄鋼及び高所での防錆性 を考慮した亜鉛めっき鋼で構成されていた。

(2)建設時の塗装は、当時の船舶・橋梁等の大型鋼構造物での施工実 績等を考慮してフタル酸樹脂系塗装システムが採用された。

(3)その後の塗装による維持保全は, 既存塗膜の状況調查を行いなが ら適宜現状を把握して、合計 9 回の全面塗替塗装を実施してきた。 (4)全面叙替塗装の時期は、塗膜劣化の影響が素地金属（鉄鋼・覀鉛 めっき鋼）にまで及ばないようにする観点から、污れ・変退色等に より塔体全体の美観機能が損なわれ始めた時点を目安としている。 (5)塗り重衫塗装システムの採用は、素地金属の防錆上、既存塗膜に 塗膜を塗り重䃿ることにより、腐食因子や腐食促進因子を素地金属 から遮断するのが最も効果的であるとの判断による。

(6)塗替塗装システムは、既存塗膜の劣化部分のみ [下地調整 $]$ [補修 塗り］を行い、健全部分は塗装下地として活用して［中塗り］及び [上塗り］を全面に塗装している。なお［補修塗り］に使用する塗 料は、既存塗膜の劣化状況に応じて選定して施工してきている。

\section{6. おわりに}

東京タワーの建設時及び今日までの塗装による維持保全に採用し てきたフタル酸樹脂系塗装システムは、鋼構造物の汎用塗装系であ るが、 55 年経過した今日でも健全な状態で機能を保持できている のは、定期的に調查を実施しながら早めに処置をする計画的な維持 保全の重要性を実証している。今後も継続して塗装による維持保全 を行いながら、長寿命化・環境負荷低減一の対応等を検討していく。

最後に、東京タワーの塗装による維持保全に、長年にわたりご協 力いただいている日本電波塔株、㐺日建設計、関西ペイント侏並び に平岩塗装(株の関係各位に感謝の意を表します。

\section{参考文献}

1) 内藤, 鶴田他：東京タワー特別記事，建築界 第 8 号 4 刊, pp. 1 34, 1959

2) 大澤, 白石他: 東京タワー塗装の劣化調査, 日本建築学会大会学術講演梗 概集 A, pp. $669 \sim 670 ， 1987$

3) 杉本, 大澤他 : 鋼構造物の塗装システム その 2 , 日本建築学会大会学術 講演梗概集 A, pp. $1129 \sim 1130,1992$

4) 大澤 : 鋼構造物の維持管理 東京タワー, 日本建築学会大会学術講演梗概 集 A, pp. 85〜88, 2002

5）常木, 國津, 大澤, 西野: 高度情報化に対応した「東京タワー」の構造体 の進化とメンテナンス、JSSC 第 71 号, pp. 7〜11, 2009

[2013 年 9 月 13 日原稿受理 2013 年 12 月 11 日採用決定］ 